\title{
A new species of the genus Trypogeus Lacordaire, 1869 (Coleoptera: Cerambycidae) from China
}

\author{
Новый вид рода Trypogeus Lacordaire, 1869 \\ (Coleoptera: Cerambycidae) из Китая
}

\author{
Alexandr I. Miroshnikovi, 2, Bin Liu ${ }^{3}$ \\ А.И. Мирошников ${ }^{1,2}$, Б. $\Lambda_{\text {ью }}{ }^{3}$
}

\footnotetext{
Russian Entomological Society, Krasnodar, Russia. E-mail: miroshnikov-ai@yandex.ru

2 Sochi National Park, Moskovskaya str., 21, Sochi, Krasnodar region 354002 Russia.

${ }^{3}$ Bin Insect Taxonomy Studio, No.16, Xizhaosi Street, Dongcheng District, Beijing 100061, P. R. China. E-mail: BinLiu_82@163.com Русское энтомологическое общество, Краснодар, Россия.

2 Сочинский национальный парк, ул. Московская, 21, Сочи, Краснодарский край 354002, Россия.
}

KEY WORDS: Coleoptera, Cerambycidae, Trypogeus, China, new species.

КЛЮЧЕВЫЕ СЛОВА: Coleoptera, Cerambycidae, Trypogeus, Китай, новый вид.

ABSTRACT. A new species, Trypogeus guangxiensis Miroshnikov et Liu, sp.n., is described from the Guangxi Zhuang Autonomous Region, China. Thus, the fauna of that country currently contains 4 species of the genus Trypogeus Lacordaire, 1869. A key to the Chinese species is given, based on male characters.

РЕЗЮМЕ. Описывается новый вид Trypogeus guangxiensis Miroshnikov et Liu, sp.n. из ГуансиЧжуанского автономного района (Китай). Таким образом, в фауне этой страны в настоящее время насчитывается 4 вида рода Trypogeus Lacordaire, 1869. Дана таблица для определения китайских видов на основании признаков самцов.

\section{Introduction}

Until recently, only two species of the genus Trypogeus Lacordaire, 1869 have been known to occur in China [Pic, 1903; Gressitt, 1951; Miroshnikov, 2014; Vives, 2015]. Besides this, as noted by Miroshnikov [2014], the determination of the male of T. aureopubens (Pic, 1903), recorded from the Xishuangbanna Dai Autonomous Prefecture, Yunnan [Weigel et al., 2013], requires clarification. Through the courtesy of Dr. Andreas Weigel (Wernburg, Germany), of us (A.M.) has been privileged to restudy this male. Eventually, A. Weigel has since correctly identified that specimen as representing $T$. superbus (Pic, 1922), a species earlier reported only from Vietnam and Laos [Pic, 1922, 1927; Miroshnikov, 2014; Vives, 2015].

The present paper puts on record another, new species from the Guangxi Zhuang Autonomous Region. The holotype is kept in the collection of the Bin Insect Taxonomy Studio, Beijing, China (cBITS)
As a result, the fauna of China currently encompasses 4 species of Trypogeus. A key to them is also presented, based until now on male characters.

Trypogeus guangxiensis Miroshnikov et Liu, sp.n. Figs $1-8$.

MATERIAL. Holotype $\sigma^{7}$ (cBITS), China, Guangxi Zhuang Autonomous Region, Jinxiu County, Laibin City, Daojiang Village, Pingban Tun, Dayaoshan Mt., $1215 \mathrm{~m}, 24^{\circ} 5^{\prime} 31.25^{\prime \prime} \mathrm{N} / 110^{\circ} 10^{\prime}$ 42.52"E, 21.VIII.2015, leg. Jin-Teng Zhao.

DIAGNOSIS. This new species differs from all continental congeners by the curved metatibiae in the male (Figs 813 ) and seems to be especially similar to T. gressitti Miroshnikov, 2014, from which it differs clearly, besides a shape of the metatibiae, in the other characters of the male, in particular, a completely dark scutellum, a weaker impression between the upper and lower discal tubercles of the pronotum, the slightly shorter antennae, a weak puncturation and darker coloration of the elytra, except for a light fascia at their base, the structure of the genitalia. Besides this, T. guangxiensis sp.n. differs from three other Chinese species by the elytra noticeably stronger diverging along suture at the apex (Figs $8,11-13$ ), as well as from T. aureopubens (Pic, 1903) by a dichromatic (dark and light) coloration and less strongly developed lateral tubercles of the pronotum, from $T$. sericeus (Gressitt, 1951) by the evidently darker elytra, except for a light fascia at their base, from T. superbus (Pic, 1922) by a completely dark scutellum, and from both former species also by the presence of only four discal tubercles of the pronotum and slightly shorter antennae.

DESCRIPTION. Male. Body length $13.2 \mathrm{~mm}$, humeral width $3.75 \mathrm{~mm}$. Head dorsally predominantly between eyes and in area of antennal tubercles black-brown, remaining parts red-yellow, on ventral and lateral sides black and dark brown with a partly dark red-brown gula; eyes mainly brown; mandibles mostly black; in dorsal view, antennomeres 1 almost completely, antennomeres 2 and 4 partly, antennomeres 3 mostly red-yellow and yellowish-red, remaining parts black- brown and dark brown, partly with a 


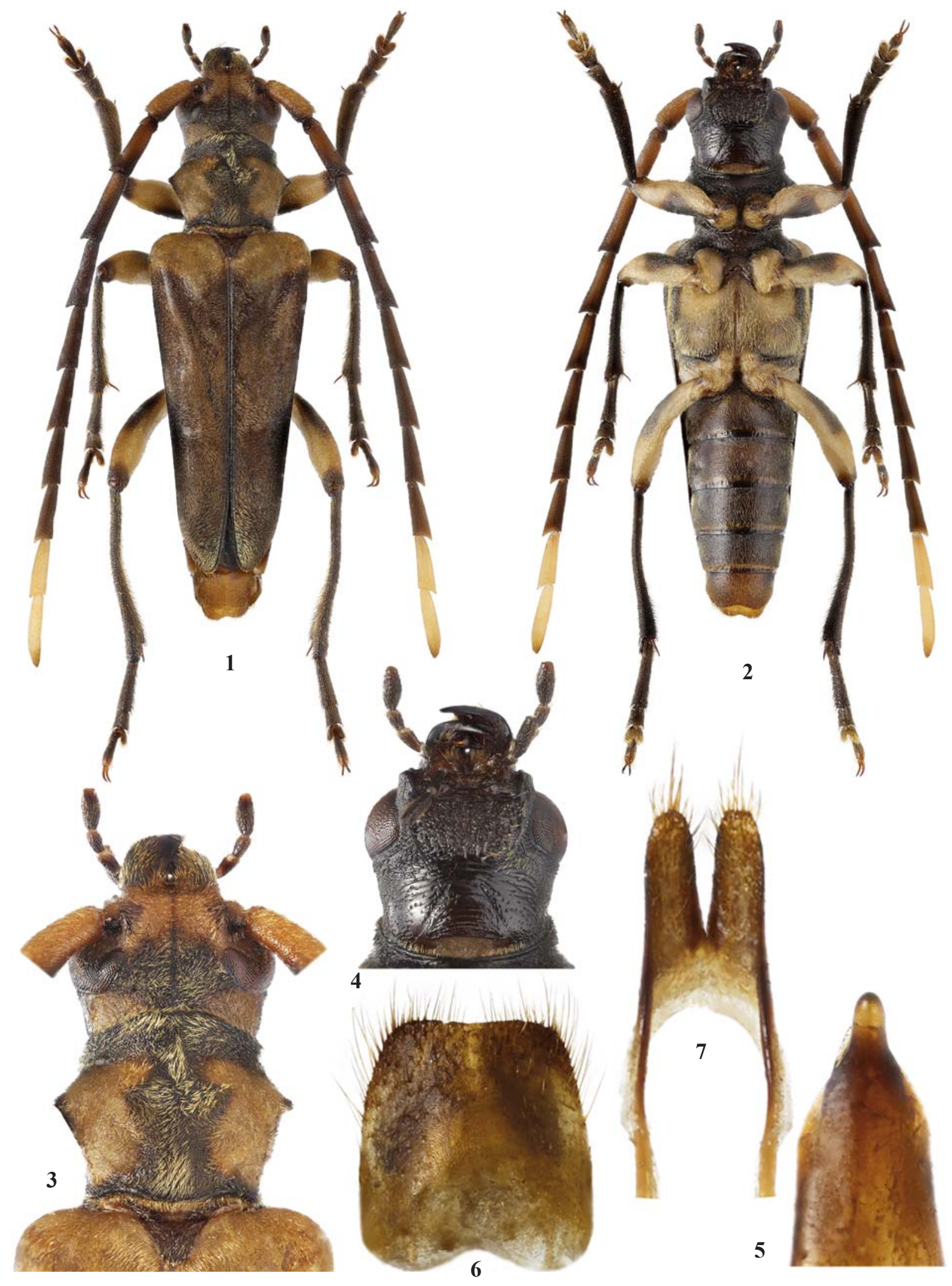

Figs 1-7. Trypogeus guangxiensis sp.n., holotype male: $1-2-$ habitus; 3 - head and pronotum; 4 - head; 5 - apex of penis; $6-$ tergite VIII; 7- apical part of tegmen; 1, 3, 6 - dorsal view; 2, 4-5, 7 - ventral view.

Рис. 1-7. Trypogeus guangxiensis sp.n., голотип, самец: 1-2 - общий вид; 3 - голова и переднеспинка; 4 - голова; 5 - вершина пениса; 6 - 8-й тергит; 7 - вершинная часть тегмена; 1, 3, 6 - сверху; 2, 4-5, 7 - снизу. 
red tint, only apical external angle of antennomeres $8-9$ yellowish, antennomeres $10-11$ beige, thereby last antennomere slightly infuscate apically; in ventral view, antennomeres 1-4 and 10-11 about the same coloration as on dorsal side, antennomeres 5-6 partly red-yellow and partly dark brown, antennomeres 7-9 almost entirely dark brown and brown, only over a small part reddish-yellow; pronotum by a wide fascia at apex, by a narrow fascia at base, by a median, wide, longitudinal stripe with a peculiar pattern and on lateral tubercles apically black-brown, remaining surface red-yellow, as in Figs 1, 3; scutellum completely dark brown; elytra with a contrasting red-yellow fascia at base, as in Fig. 1, behind with a complicated pattern consisting of brown and dark brown tones and partly along lateral margin black; proand mesosterna entirely, metasternum on episterna, adjoining lateral surface and in apical part black-brown and brown, remaining surface yellow; (visible) sternites 1-4 brown with different tones, last (visible) sternite mainly reddish, last (visible) tergite almost completely red-yellow; femora yellow, in basal part apically black-brown, tibiae entirely and tarsi mostly black, two last tarsomeres partly red-brown, coxae almost completely yellow.

Head noticeably narrower than pronotum at level of lateral tubercles; dorsally with a very dense and confluent
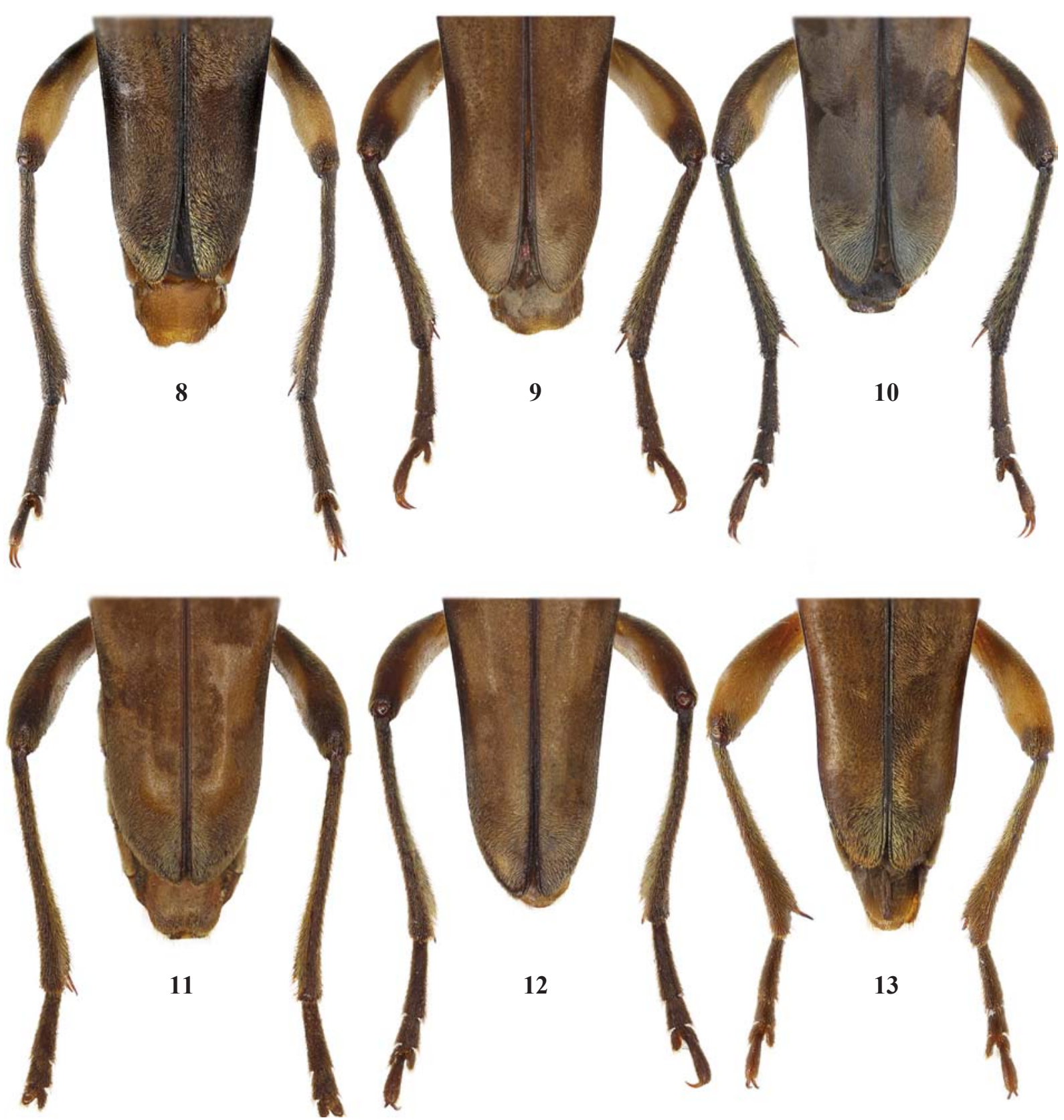

Figs 8-13. Trypogeus ssp., apical part of elytra and posterior legs of males: $8-$ T. guangxiensis sp.n.; $9-$ T. gressitti; $10-$ T. murzini; 11 - T. aureopubens; $12-13-$ T. superbus; 8-12 -holotypes.

Рис. 8-13. Trypogeus ssp., вершинная часть надкрылий и задние ноги самцов: $8-T$. guangxiensis sp.n.; $9-T$. gressitti; $10-$ T. murzini; 11 - T. aureopubens; 12-13 - T. superbus; 8-12 - голотипы. 
puncturation; a clear, longitudinal median groove; with moderately developed antennal tubercles; mandibles long, strongly curved, right mandible, like in all congeners, with a large tooth at inner margin; eyes deeply emarginate, slightly convex, with not too large, but distinct ocelli; genae short; ventral side between eyes in area of submentum with a coarse, but not too deep, scabrous puncturation; wellexpressed transverse wrinkles on gula; on either side of it with a sharp, irregular, sparse puncturation and a clearly rugose sculpture; antennae noticeably longer than body, about reaching the apex of elytra by antennomere 9 .

Pronotum at level of lateral tubercles 1.35 or 1.27 times as wide as width at base and length, respectively; apex barely wider than base; lateral tubercles very well-developed, sharpened at apex; disk with four well-developed tubercles, two at base and further two in the middle; with a very dense and confluent punctures and a most delicate puncturation. base.

Scutellum triangular, subequal in length and width at

Elytra 2.11 times as long as humeral width; regularly strongly narrowed towards apex; noticeably diverging along suture at apex; each elytron rounded at apex; with a weak puncturation.

Prosternal process very narrow between coxae; mesosternal process moderately wide; metasternum with a small, dense, rugose puncturation; metepisterna very wide, moderately narrowed towards apex; sternites with a small, dense, partly heterogeneous puncturation; last (visible) sternite with a well-developed emargination at apex.

Legs relatively robust, moderately long; femora thickened, but not claviform; metatibiae very noticeably curved about the middle, as in Figs 1-2, 8, clearly emarginate at apex; metatarsomere 1, 1.54 times as long as metatarsomeres 2 and 3 combined.

Recumbent setation well-developed; its silky looks and location on elytra being there contrasting iridescent like in other congeners.

Genitalia as in Figs 5-7.

ETYMOLOGY. The name of the new species is derived from the Guangxi Zhuang Autonomous Region, China, the terra typica.

\section{Key to Chinese species of TRYPOGEUS, BASED on $O^{7}$ CHA-} RACTERS

1. Metatibiae straight, at least without clear curvature in the middle (Figs 11-13); elytra noticeably weaker diverging along suture at apex (Figs 11-13); pronotum on disk with five clear tubercles, if with four ones (in T. superbus), then scutellum usually completely light
- Metatibiae very clearly curved about the middle (Fig. 8); elytra noticeably stronger diverging along suture at apex (Fig. 8); pronotum on disk with four clear tubercles; scutellum completely dark (Figs 1,3 ).

T. guangxiensis sp.n.

2. Head dorsally and pronotum with combined black-brown (or dark brown) and red-yellow coloration, only head can be completely dark (in $T$. sericeus); scutellum dark or light

3

- Head dorsally, pronotum and scutellum entirely blackbrown or dark brown .................. T. aureopubens (Pic)

3. Pronotum on disk with four clear tubercles, two before middle and also two at base; scutellum usually completely light, can be partly infuscate only ........ T. superbus (Pic)

- Pronotum on disk with five clear tubercles, two located before middle and three at base; scutellum entirely dark or black T. sericeus (Gressitt)

ACKNOWLEDGEMENTS. We are very grateful to Kirill V. Makarov (Moscow Pedagogical State University, Russia) who has helped with the preparation of all photographs and to Jinteng Zhao (Guangxi, China) for the offer of this invaluable material used in this study and his magnificent field work. The first author's sincere thanks also go to Andreas Weigel for the opportunity to study a specimen of Trypogeus superbus from his collection.

\section{References}

Gressitt J.L. 1951. Longicorn beetles of China // Lepesme P. (ed.). Longicornia. Études et notes sur les Longicornes. Vol.2. Paris: Paul Lechevalier. 667 p. +22 pls.

Miroshnikov A.I. 2014. The genus Trypogeus Lacordaire, 1869: an annotated check list and descriptions of new species from Cambodia and Laos (Coleoptera: Cerambycidae) // Konstantinov A.S., Ślipiński S.A., Solodovnikov A.Yu. (eds.). Advances in studies on Asian cerambycids (Coleoptera: Cerambycidae). Papers by Alexandr I. Miroshnikov, dedicated to the memory of Dr. Judson Linsley Gressitt. Krasnodar - Moscow: KMK Scientific Press Ltd. P.51-71.

Pic M. 1903. Diagnoses préliminaires de Longicornes du Yun Nam // L’Échange, Revue Linnéenne. Ann.39. No.221. P.121.

Pic M. 1922. Nouveautés diverses // Mélanges Exotico-Entomologiques. Fasc.36. P.1-30.

Pic M. 1927. Coléoptères du Globe // Mélanges Exotico-Entomologiques. Fasc.50. P.1-36.

Vives E. 2015. Revision of the genus Trypogeus Lacordaire, 1869 (Cerambycidae, Dorcasominae) // ZooKeys. Vol.502. P.39-60.

Weigel A., Meng L.-Z., Lin M.-Y. 2013. Contribution to the fauna of longhorn beetles in the Naban River Watershed National Nature Reserve. Formosa Ecological Company. 219 p. 